Article

\title{
Social Inclusion or Gender Equality? Political Discourses on Parental Leave in Finland and Sweden
}

\author{
Mikael Nygård ${ }^{1}$ and Ann-Zofie Duvander ${ }^{2,3, *}$ \\ ${ }^{1}$ Department of Social Policy, Åbo Akademi University, 65100 Vasa, Finland; E-Mail: mikael.nygard@abo.fi \\ 2 Department of Sociology, Stockholm University, SE-106 91 Stockholm, Sweden; \\ E-Mail: ann-zofie.duvander@sociology.su.se \\ ${ }^{3}$ Department of Humanities and Social Sciences, Mid University, SE-831 25 Östersund, Sweden \\ * Corresponding author
}

Submitted: 12 November 2020 | Accepted: 8 February 2021 | Published: 11 June 2021

\begin{abstract}
During the 2010s, both Finland and Sweden made advancements in their parental leave systems by widening the right to paid parental leave to a greater diversity of family constellations and investing in gender-equal leave distribution through longer leave periods reserved for the father. However, in the latter respect, Sweden has remained more successful than Finland. This article analyses government and political party discourses in Finland and Sweden during the 2010s in pursuit of an explanation to this difference and for understanding how ideas on social inclusion and gender equality have been used to drive, or block, policy reforms in the field of parental leave. The results show that the parental leave discourses have become influenced by ideas on social inclusion and gender equality in both countries, but in somewhat different ways. While gender equality has retained a stronger position in the Swedish discourse and its policy, social inclusion, and notably the rights of same-sex parents, have become more visible in the Finnish. However, the results also show that both ideas have remained contested on a party level, especially by confessional and nationalist-populist parties.
\end{abstract}

\section{Keywords}

2010s; Finland; gender equality; government; parental leave distribution; political discourse; political party; Sweden

\section{Issue}

This article is part of the issue "The Inclusiveness of Social Rights: The Case of Parental Leave Policies" edited by Sonja Blum (University of Hagen, Germany) and Ivana Dobrotić (University of Oxford, UK / University of Zagreb, Croatia).

(C) 2021 by the authors; licensee Cogitatio (Lisbon, Portugal). This article is licensed under a Creative Commons Attribution 4.0 International License (CC BY).

\section{Introduction}

From an international perspective, Finland and Sweden appear similar when it comes to parental leave policy. Both are Nordic dual earner/dual carer models with socially including and gender-equal parental leave systems that not only acknowledge leave rights for a diversity of families, but also seek to share leave more equally between mothers and fathers (Haataja \& Nyberg, 2006). Parental benefits are income-related with relatively high replacement rates and a minimum flat-rate allowance for parents without prior incomes. In both countries, parental leaves are financed through contri- butions mainly from the employer (Försäkringskassan, 2020a; Lammi-Taskula \& Takala, 2009).

During the 2010s, both Finland and Sweden have conducted reforms that aimed towards higher social inclusion in their parental leave systems, for example, by strengthening the rights of single parents and same-sex parents (Wong, Jou, Raub, \& Heymann, 2019). However, while Sweden has also simultaneously strengthened its already more gender-equal system, Finland has been less successful in this respect. The Swedish leave system is not only more generous and flexible than the Finnish, but it also grants parents longer periods of leave reserved for each parent. This, in turn, is linked 
to a higher leave uptake rate of Swedish fathers (Eydal et al., 2015; Eydal, Rostgaard, \& Hiilamo, 2018). For instance, in 2016, Swedish fathers used $28.2 \%$ of all leave, but Finnish fathers used only $10.5 \%$ (NOSOSCO, 2017 , p. 56). Correspondingly, in 2015 , the employment rate of Swedish mothers with children under three surpassed that of Finnish mothers (Statistics Finland, 2017). Previous research has explained this divergence in gender-equal leave policy by pointing at the more prominent role that trade unions and employers play in the Finnish policymaking process (Lammi-Taskula \& Takala, 2009). It has also suggested that the principle of gender equality is stronger in Sweden while traditional family values and notions of freedom of choice remain more salient in Finland (Hiilamo \& Kangas, 2009; Ylikännö, Hakovirta, \& Salin, 2016). However, given the centrality of political parties in family policymaking (e.g., Cedstrand, 2011; Häusermann, Picot, \& Geering, 2013; Nyby, 2020), there is surprisingly scant research on their role in recent developments of Finnish and Swedish parental leave policy.

This article contributes to the literature by analysing how governments and leading parties in both countries have politicised parental leave rights during the $2010 \mathrm{~s}$ against the backdrop of ideas on social inclusion and gender equality. Both these ideas pertain to the fundamental question of who is to be considered a parent and who can claim parental leave. However, we define social inclusion as the idea of how this right is to be distributed between different family constellations (cf. Wong et al., 2019), while gender equality concerns how it is to be distributed between women and men within families (Auth \& Martinek, 2017; Eydal et al., 2018; see also section three). Based on this, our aim is to analyse government and party programmes from both countries to discern how these ideas have been understood and used in discourses legitimating, or contesting, parental leave reforms. If there is discursive convergence, this may not only suggest a transfer of ideas and social learning (Hulme, 2005), but also indicate that policy convergence is likely to follow.

The article contributes to the literature in at least two ways. First, it sheds light upon the role of political parties, discourses and ideas for parental leave policy. Second, it helps to assess whether political discourses on parental leave have remained distinct or become more similar in Finland and Sweden during this period. Such knowledge will contribute to understanding policy transfers between neighbouring countries.

The rest of the article is structured in the following way. Next, we shortly present the development of the Finnish and Swedish parental leave systems to contextualise our analysis. The following theoretical section discusses the role of political parties and ideas in parental leave policy. Thereafter, our data and methods are presented. The penultimate section presents our findings, and the final section concludes and discussed the findings.

\section{The Finnish and Swedish Parental Leave Systems: Historical Milestones and Current Outlooks}

In both Finland and Sweden, the origins of parental leave can be traced to the early 1900 s and the ambition to protect working mothers in relation to childbirth (Wennemo, 1994). Over time, both systems have developed into highly generous systems that acknowledge both a diversity of families and gendered rights to parental leave (Dobrotić \& Blum, 2020; Eydal et al., 2018).

In Finland, the issue of maternity insurance was discussed already in the 1920s, but the introduction of such a social right was delayed until 1963 when mothers became eligible for a nine-week maternity allowance as a part of the National Health Insurance. Since then, the leave rights have been extended several times and become more socially including as well as more genderequal. From the beginning, the parental leave system catered for a diversity of families, both working-class and rural families. During the following decades, also other family types, such as adoptive parents, were included in the system. A major step towards higher social inclusion was taken in 2014, when a government committee (STM, 2015) suggested leave rights also for 'new' types of families, such as same-sex parents (so-called rainbow families). In 2017, these families received leave rights, and in 2019 leave rights for single parents and transgender persons were expanded (see Moring \& Lammi-Taskula, 2021).

Alongside parental leave, also universal public childcare saw daylight in Finland in 1973. The right to claim public childcare was expanded to all children under three in 1990 and to all children under school age in 1996. In order to relieve the pressure on public childcare services and support the home care of small children, a child home-care allowance (Kotihoidon tuki) was introduced in 1985 (Hiilamo, 2002). This benefit, which is mostly used directly after the parental leave period, has become quite popular, especially among mothers with lower education and more insecure labour market position (e.g., Salmi \& Lammi-Taskula, 2014)

Since 1978, Finnish fathers have also been able to claim paid parental leave, first through a two-week paid paternity leave (dependent upon the mother's permission) and since 1991 through a 'daddy quota' that could not be transferred to the mother without being forfeited. They have also for some time had the right to use the shareable period of parental leave, even if few fathers have used this option. The one-week quota was extended to three weeks in 1993, but at the expense of the total length of parental leave. In 2003, fathers received a two-week non-transferable leave bonus if they used two weeks of the transferable parental leave period. This combined leave became the 'father's month' in 2007 , but while it was more flexible than before, it was still tied to the usage of the transferable parental leave (Lammi-Taskula \& Takala, 2009). In 2010, the leave bonus was extended to four weeks, which meant that 
the father could be on leave for six weeks in total if he used two weeks of the transferable parental leave (Salmi \& Lammi-Taskula, 2014). In 2011, the parental leave committee (STM, 2011) suggested an even more ambitious reform for increasing gender equality, and one alternative in this proposal was to introduce threemonth non-transferable 'quotas' for both the mother and the father with a further three-month period that could be shared. However, this proposal failed to materialise and instead a nine-week quota called paternal leave was introduced in 2013, including a three-week part that could be used simultaneously with the mother (Salmi \& Lammi-Taskula, 2014).

Since 2013, there have been no further changes in the gender structure of parental leave in Finland. In 2017, the centre-right government tried to reform the parental leave system in a more gender-equal way, but failed. However, in 2019, the left-centre coalition led by the Social Democrats once again placed the question of a more gender-equal parental leave on the agenda by suggesting longer quotas for both the father and the mother. The government's proposal including a 6.4-month reserved quota for each parent with a transferable period of 0-63 days was presented in February 2021 and is scheduled to take effect in August 2022 (STM, 2021).

Meanwhile, the existing system in Finland includes 17.5-week maternity leave, a nine-week paternity leave and a 26.3-week transferable parental leave, on top of which care leave and a home-care allowance can be used for children under three. The replacement rate of parental allowance is $70 \%$ and the basic amount approx. $29 € /$ day for persons with yearly incomes under $11943 €$ (Kela, 2020).

In Sweden, the protection of working women delivering a child has also been discussed since the beginning of the 1900s (Lundqvist, 2007). Maternity leave was introduced in the 1930s, but in the beginning mainly as a means-tested benefit. A major shift in debate and policy took place in the 1960s when the voices for gender equality through women's economic independence were combined with the increasing demand for female labour in the growing public sector (Stanfors, 2007). In 1974, as a consequence of the wide cross-party support for the dual-earner family, maternity leave was replaced by parental leave. A six-month-long parental leave now became available for parents to share as they wished, with allowances replacing $90 \%$ of their incomes.

When registered partnership for same-sex couples became recognised in Sweden in 1995, one consequence was that both partners in such unions received leave rights. In 2003, same-sex parenthood was recognised, which affected female partners of biological mothers (Evertsson, Jaspers, \& Moberg, 2020). However, only in 2019 did it become possible for one parent to transfer his or her parental leave days to a partner (who is not the biological parent). This change facilitated the sharing of care among a greater number of adults and also aimed to facilitate situations of a pending adoption (for example, when one partner was inseminated) (Försäkringskassan, 2020b).

As Swedish mothers' labour force participation increased during the 1970s, the focus of the parental leave debate turned to fathers' participation in childcare. A major change came with the introduction of the fathers' quota in 1995. This reform reserved one month of the 15-month long leave period for the other parent, which was the father in most cases. The reform led to a sharp increase in the share of fathers with children under two taking up leave. Overnight, this share increased from $44 \%$ to $77 \%$ (Duvander \& Johansson, 2012). The reserved month was introduced together with a child home-care allowance (Vårdnadsbidrag) by the conservative-liberal government, but the home-care leave was later abolished by the Social-Democratic government (Ferrarini \& Duvander, 2010). The reserved month was further extended to two months in 2002, together with a one-month extension of the parental leave. In 2008, the conservative-liberal coalition introduced the so-called gender equality bonus (Jämställdhetsbonus), a tax incentive for increasing fathers' childcare participation. It also reinstalled the child home-care allowance on the municipal level. However, the gender equality bonus did not lead to major changes in fathers' uptake, and the child home-care allowance never gained popularity (Duvander \& Ellingsæter, 2016; Duvander \& Johansson, 2012). In 2016, the Social-Democratic coalition abolished both the gender equality bonus and the child home-care allowance, but reserved the third month for each parent without much resistance or even attention. Since then, a further extension of leave rights suggesting a division of the total leave period into three parts, one to each parent and one to share according to wishes, has been discussed (SOU, 2017, p. 101) but has thus far not led to any reform.

During the 1900s, the demand for female labour and the rise of gender-equal ideas in Sweden led to voices demanding public childcare expansion. This expansion gained speed in the end of the 1970s resulting in an extension of publically financed childcare provision (Gustafsson \& Stafford, 1992). However, not until the childcare guarantee and standardized fees were institutionalised at the end of the 1990s, could one speak of universal childcare (Nyberg, 2000).

Since 2002, the parental leave in Sweden is 16 months, or 8 months per each parent. The benefit is set at almost $80 \%$ of earlier income for the first 13 months, while the remaining months are replaced at a low flat rate. Parents with no prior income are entitled to a low flat-rate (today $25 €$ a day) benefit for the first 13 months (Försäkringskassan, 2020a).

\section{Parties, Ideas and the Politics of Parental Leave}

There are various theoretical explanations for the development of family policy, including parental leave (e.g., 
Wennemo, 1994). Some of these use a functional logic explaining family policy change as an outcome of structural factors and changing social needs. Another group of explanations focusses on the political struggle between ideologies and interests advocated by classes, political parties or other actors. A third group emanates from institutional theory emphasising, for example, lock-in effects and path dependency as well as policy diffusion and influential ideas (e.g., Kuebler, 2007). This article departs from the second and third of these strands suggesting that political parties play a vital role in parental leave policy development, but that these processes are influenced by institutional factors as well as ideas and policy recommendations emanating from supranational agencies, such as the European Union or the OECD.

Political parties fulfil several important functions. For instance, they formulate ideologies and programmes that provide voters with political alternatives necessary for democracy. Second, they seek enough electoral support for obtaining the parliamentary power needed for influencing legislation. In this process, they need strategies, but also compromises. This is especially true for countries with proportional voting systems and unicameral parliaments, where coalition governments are the rule (Häusermann et al., 2013; Lewin, 2020). For this article, the first of the abovementioned functions is central since it relates to how parties understand, construct and formulate propositions for policy and how they invoke influential ideas in this process (Nyby, 2020). Party programmes or election manifestos play an important role in this respect since they create identity, define core values, and provide cognitive frames for understanding and positioning themselves in relation to what is going on in the world (Freeden, 1996).

However, party ideologies do not exist in a vacuum; they evolve in tandem with the changing world. One such change is the emergence of 'new' family constellations and 'new' social needs (Nygård, Nyby, \& Kuisma, 2019). Another is the globalisation process that has highlighted the role of supranational actors and influential ideas in politics, as well as in parental leave policy. Today, national governments and political parties operate in a more open world with higher uncertainty, which has made them more susceptible to supranational ideas, social learning and policy benchmarking as ways of dealing with uncertainty (Hulme, 2005).

An example of such an idea within parental leave policy is that of social inclusion, that is, the idea that parental leave policy needs to acknowledge a greater diversity of family constellations (Wong et al., 2019). Historically, this idea is closely related to the notion of social and citizen rights and the question of whether parental leave should be based on citizenship or employment history (Dobrotić \& Blum, 2020). However, in today's globalised world, the meaning of 'inclusiveness' has become increasingly influenced by the greater variety of family constellations in need of social rights, such as same-sex parents, transgender parents or immigrant parents (cf. European
Commission, 2019; Wong et al., 2019). Consequently, the debate about social inclusion does not only concern whether the leave rights of parents in traditional, different-sex families should be based on citizenship or previous employment, but also whether such rights should pertain to other constellations of families, such as same-sex parents (see Moring \& Lammi-Taskula, 2021). During the 2000s, this interpretation of social inclusion has become notably influential in relation to same-sex or transgender couples through international treaties, such as the 2007 Yogyakarta Principles outlining central human rights for LGBT persons or policy recommendations from the OECD supporting parenting regardless of partnership status (Wong et al., 2019). For the purpose of this article, though, we do not restrict the notion of social inclusion to same-sex or LGBT couples alone. Instead, it relates to how parental leave policy addresses family diversity in general, that is, how leave rights are to be distributed between different kinds of families and especially how leave policy addresses the rights of a greater diversity of family constellations, such as singleparent families, immigrant families, as well as same-sex and LGBT couples. Other kinds of social inclusion, such as rights for parents in atypical employment or without employment, have not been the focus of the politics in Sweden and Finland during this period, probably as both mothers' and fathers' work are taken for granted.

Another influential idea underpinning parental leave policy is that of gender equality. According to Auth and Martinek (2017), gender equality can be understood in many ways involving several and interrelated policy aims and instruments. However, one of its most central aims is to increase women's integration in the labour market while simultaneously increasing men's engagement in care work, for example, through regulations on shared leave, the combination of part-time work and care work, as well as reserved leave periods for fathers. Historically, the idea of gender equality stems from the women's movement and its struggle to improve the rights and living conditions of women (Eydal et al., 2018; Hiilamo, 2002). However, in the 1990s, it also became an integral part of the influential social investment paradigm, which not only advocated gender equality as a matter of right, but also set this in connection with the objective to raise parental, and notably maternal, employment across Europe and to increase fathers' involvement in care work (e.g., Auth \& Martinek, 2017; Morel, Palier, \& Palme, 2012). For the purpose of this article, we use this as our starting point and define gender equality narrowly as an ambition to distribute parental leave equally within the family, that is, between the mother and the father.

Political parties, as well as social partners and women's organisations, have played a central role in the shaping of the parental leave systems in Finland and Sweden. When it comes to parties, they have done so according to their ideological beliefs (e.g., Hiilamo, 2002), but also under the influence of dominant ideas, 
such as social inclusion and gender equality. Although these ideas may come in many forms, and the ways they become adopted by parties may differ between countries, they play an important role in how parties understand policy problems, how they create solutions and what policy claims they make (Häusermann et al., 2013; Nyby, 2020). During the first decades of the post-war period, the Finnish and Swedish discussions regarding social inclusion mainly concerned whether parental leave should be employment-based or universal, residence-based, social rights (cf. Dobrotić \& Blum, 2020). Whereas the former notion has been close to social democracy, residence-based rights have been close to parties representing farmers or conservatives. In both countries, these principles became combined in the post-war parental leave systems, with the former covering salaried parents and the latter providing minimum income protection for other parents (Hiilamo, 2002). In the 1990s and 2000s, however, the question of how to address diversity among families in Finnish and Swedish parental leave became increasingly highlighted by notably leftist and green parties. By contrast, conservatives and especially confessional parties remained reserved to such ambitions (Hiilamo \& Kangas, 2009).

Since the 1960s, the idea of gender equality has also become increasingly important in both Finland and Sweden. This idea became endorsed by the Swedish Social Democrats already in the 1960 and later spread to other parties (Cedstrand, 2011). It became a central political objective in Swedish politics and has also influenced parental leave policy in many ways, not least through the introduction of the gender-neutral reserved monts of parental leave, also known as daddy (and mommy) months (Ferrarini \& Duvander, 2010). However, the use of state-sanctioned regulations to achieve more equal leave uptake has remained a controversial issue for some parties, notably confessional parties that saw such statesanctioned regulations as infringements upon the freedom of families (Hiilamo \& Kangas, 2009). This has also been the case in Finland, where the discussion regarding gender-equal parental leave surfaced in the 1970s and then started to grow in importance. However, due to the scepticism towards state-sanctioned regulation of leave between the mother and the father among the Centre Party, the Finns Party and the Christian Democrats, Finland has not thus far granted fathers the same rights to reserved leave as in Sweden (Lammi-Taskula \& Takala, 2009).

In the 2000s, most of the leading parties in Finland and Sweden have endorsed the idea of gender equality as a general objective in parental leave policy, but there is still an ideological divide concerning how parental leave should be divided between the mother and the father, and whether this should be sanctioned by the state. While the political left has largely advocated equal sharing of parental leave with a high degree of state sanctioning, conservative and confessional parties have generally opposed such ideas (Hiilamo \& Kangas, 2009).
This divide is also visible in the discussion about the child home-care allowance, which is a contested part of the Finnish family leave system. In general, though, Swedish parties seem to have been more positively disposed to the idea of gender-equal parental leave than their Finnish counterparts. This may be a result of longer periods of Social-Democratic rule (Cedstrand, 2011), but it may also relate to country differences in public opinion, for instance, when it comes to mothers' attitudes towards family roles (Weckström, 2014) or the idea of equal division of paid and unpaid work between spouses (Ylikännö et al., 2016).

To sum up, parties play an important role in the politics of parental leave. They participate in the policymaking process and do so according to different ideologies and ideas, such as social inclusion and gender equality. Based on this, we expect to find a growing influence of social inclusion and gender equality ideas on government and party discourses on parental leave in Finland and Sweden during the 2010s. Secondly, however, we expect these ideas to be aligned along ideological lines, with the political left advocating higher levels of social inclusion and state-regulated gender equality and conservative/confessional parties being more hesitant towards such ideas. In the next section, we describe how we investigated these hypotheses methodologically.

\section{Data and Method}

We conducted qualitative content analyses of government programmes and government declarations, party election programmes, as well as various reports from committees preparing reforms in this area. Documentary data of this kind provides rich and ample information concerning how preferences, interests and ideological values penetrate discourses influencing policy changes (Nygård et al., 2019). Government programmes (Finland) list the policies to be conducted during the government term as well as the motivations behind them. Since such programmes are not available in Sweden, we used government declarations given by the Prime Minister (PM) at the opening of the Swedish parliament. It should be noted, though, that government documents mostly reflect compromises between the governing parties and do not constitute the view of a single party. Therefore, we also analysed election programmes and programmes on family policy published by the seven largest parties in each country. For Finland, this group included the Social Democratic Party, the Conservatives, the Centre Party, the Finns Party, the Left Alliance, the Green Party and the Christian Democrats. For Sweden, it included the Social Democrats, the Conservatives, the Centre Party, the Sweden Democrats, the Left Party, the Christian Democrats and the Liberals. By studying such programmes, we can identify and follow discourses on parental leave on both a governmental and a party level and study how they have related to questions on social inclusion and gender equality. 
In total, we analysed seven government programmes and 33 election manifestos and family policy programmes from Finland, as well as 11 government declarations and 21 election programmes from Sweden (see Supplementary File). Moreover, a number of committee reports and government bills were analysed for the sake of depth and context. In Finland, the political constellation during the 2010s has been characterised by broad coalitions, including the centre-right coalition of Kiviniemi (2010-2011), the right-left coalitions of Katainen and Stubb (2011-2014 and 2014-2015), the centre-right coalition of Sipilä (2015-2019), and the left-centre coalition of Rinne/Marin (from 2019). In Sweden, the political landscape has been more visibly characterised by 'bloc politics,' minority coalitions led by the Social Democrats and the strength of the populist Sweden Democrats (Lewin, 2020). We studied the rightcentre "Alliance" coalition of Reinfeldt (2010-2014), the Löfven I coalition between the Social Democrats and the Greens (2014-2018) and the Löfven II coalition also led by the Social Democrats. Noteworthy is also that the studied period has been influenced by the economic recession (more so in Finland than in Sweden), an asylum crisis in 2015-2016 and a continuous fall in fertility in both countries. Due to limited space, our focus is restricted to the period prior to the Covid-19 pandemic.

The analytical two-step approach involved qualitative content analysis with a mix of 'inductive' and 'deductive' elements (Hsieh \& Shannon, 2005). First, we conducted general readings of the programmes to get a sense of the whole and locate text relating to parental leave. Second, we identified direct or indirect mentions of parental leave, which we then coded according to whether they expressed a positive, negative or neutral position regarding ideas on social inclusion and gender equality. For instance, a mention supporting extended parental leave rights for a certain type of family, e.g. same-sex parents, was coded positively for social inclusion. Similarly, a mention supporting the introduction of reserved periods of parental leave was coded positively for gender equality. This analytical approach can be seen as a straightforward, but effective, procedure for analysing discursive patterns underpinning parental leave reform. Although we focus on discourses, we did not use discourse analysis since our interest related more to the categorisation of meaning rather than the revelation of underlying power constellations (Boréus \& Bergström, 2017). A limitation is that this strategy says little about the actual policymaking process or the roles of other actors. In the following, we present our results using text excerpts (translated from Finnish and Swedish by the authors) to substantiate our interpretations.

\section{Findings}

\subsection{Finland}

In Finland, ideas on both social inclusion and gender equality were discussed in relation to parental leave policy during the 2010s (see Table 1).

However, the idea of social inclusion was addressed only sparsely in government programmes, with the 2013 structural-political programme by PM Katainen advocating the rights of adoptive parents and the 2019 government programme by PM Marin acknowledging the rights of 'diverse' families:

Table 1. Overview of government and party discourses regarding parental leave in Finland during the 2010s.

\begin{tabular}{llll}
\hline & 2011-2014 & 2015-2018 & 2019- \\
\hline $\begin{array}{l}\text { Social inclusion } \\
\text { Government discourse }\end{array}$ & $\begin{array}{l}\text { GP (Katainen) 2013+ } \\
\text { STM 2011: } 12+\end{array}$ & STM 2015:45+ & GP (Rinne/Marin) 2019 (+) \\
Party discourse & $\begin{array}{l}\text { SocDem/Left/Green }+ \\
\text { Cen }(+)\end{array}$ & Left/Cen (+) & $\begin{array}{l}\text { SocDem/Left/Con }+ \\
\text { Green (+) }\end{array}$
\end{tabular}

Gender equality

Government discourse

Party discourse

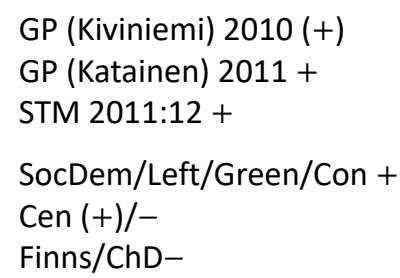

$$
\text { STM 2015:45 (+) }
$$$$
\text { GP (Rinne/Marin) } 2019+
$$

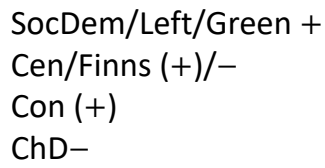

\author{
SocDem/Left/Green/ \\ Con + \\ Cen/ChD-
}

Notes: 'Government discourse' relates to government programmes (GP) or committee reports (STM). 'Party discourse' relates to party election manifestos or similar programmes. ' + ' denotes a positive position and '-' a negative position on social inclusion/gender equality. 'SocDem' is an abbreviation for Social Democrats., 'Left' for Left Alliance, 'Cen' for Centre Party, 'Con' for Conservatives, 'Finns' for Finns Party, 'Green' for Green League and 'ChD' for Christian Democrats. Parentheses indicate an indirect position. The data can be retrieved from the Supplementary File. 
The [parental leave] reform will be conducted in a way that treats all families equally, including those representing diversity. (Finnish Government, 2019, p. 135)

Meanwhile, the question of equal parental leave rights for adoptive, single and same-sex families was discussed more extensively in the 2011 and the 2015 committee reports, which ultimately led to the 2017 and 2019 reforms improving leave rights for 'rainbow' parents, as well as single parents and transgender parents. On the party level, social inclusion, including rights for same-sex couples, was discussed most extensively by the Social Democrat and the Greens, but also the Left Alliance, while the Centre Party and the Conservatives mentioned the right of single mothers and the including of close relatives in the child home-care system. No claims relating to social inclusion were found in the programmes by the nationalist-populist Finns Party or the Christian Democrats.

As to the idea of gender equality, the ambitions to achieve higher gender equality in the form of higher levels of father's leave uptake was clearly stated in the 2011 committee report. Furthermore, both the Kiviniemi and the Katainen governments explicitly advocated this objective. However, while the former government, led by the Centre Party, did not say how this was supposed to be achieved, the latter was more specific by pinpointing the use of earmarked leave:

The intention is to increase the earmarked leave for fathers, and to make fathers' use of leave more flexible. (Finnish Government, 2011, p. 70)

Katainen's government, which also included the Social Democrats, thus championed higher paternal leave uptake and partly followed the recommendations given by the 2011 committee report by introducing a nineweek quota for fathers in 2013. It also criticised the child home-care leave for being detrimental to the government's objective to increase gender equality and maternal employment. However, it refrained from a reform of this benefit and instead chose to introduce a flexible care allowance for families with a child under three years of age. Subsequent governments in Finland have thus far refrained from reforming the child home-care allowance. In 2017, the question of a more gender-equal parental leave system resurfaced when the Sipilä centre-right government unexpectedly launched a reform of the system. This initiative was supported by the opposition as well as the major trade unions and the employers' central organisation, but was not mentioned in the 2015 government programme (Elomäki, Mustosmäki, \& Koskinen Sandberg, 2020). That the Centre Party halted the reform in 2018 was probably strategically motivated. In the face of the incoming 2019 parliamentary election, it wanted to show its voters that it stood its ground on the preservation of the child home-care allowance. However, in the programme of Marin's current left-centre coalition, the need to reform parental leave in a gender-equal direction through equal leave quotas for the mother and the father was put back on the table, however with the child home-care allowance untouched:

Together with social partners, we will achieve an ambitious parental leave reform that supports the wellbeing of families. The objective is for leave and care duties to become more evenly distributed between parents....The reform will give mothers and fathers an equal quota of leave months....The child home-care allowance continues in its current form. (Finnish Government, 2019, p. 135)

On the party level, gender-equal parental leave, and notably the question of the child home-care leave, has created a division between the Centre Party, the Finns Party and the Christian Democrats on one side, and the Leftist parties and the Conservatives on the other. While the former camp has supported the home-care leave, the latter has suggested a shortening or even removal of this benefit. As to the question of state-regulated gender equality through quotas, the Christian Democrats has been the only party explicitly opposing such an idea. The Centre Party and the Finns Party have taken a lukewarm position, while the Conservatives, as well as the parties on the left and the Greens, have all supported this idea. Already in 2010-2011, the Left Alliance and the Greens suggested a six-month-long quota for both the mother and the father with a six-month shareable period, extending the total leave period to 18 months. In 2014, the Social Democrats proposed a similar model, but with shorter parental quotas (three months) and a nine-month shareable leave period. In 2019, they suggested a shortening of the shareable leave to six months while simultaneously proposing a one-year leave period with a flat-rate parental allowance (that would substitute the home-care allowance). The Greens and the Social Democrats both referred to the Swedish system of individualised leave right as a best practice, but so did also the Christian Democrats in terms of flexible leave rights. The Conservatives suggested a similar parental leave reform as the Social Democrats, but with a shorter duration. The Finns Party suggested a three-month quota for each parent with a nine-month shareable period, while the Centre Party suggested an extension of the current daddy quota. By contrast, in the 2018 family policy programme by the Christian Democrats, leave quotas were seen as an infringement upon the family:

The Christian Democrats do not support leave quotas between parents, since this would infringe upon the freedom of choice and lead to unnecessary regulation. (Christian Democrats, 2018a, p. 20)

To sum up, while the Finnish discourse on parental leave has clearly been influenced by both ideas on social 
inclusion and gender equality, it seems that the latter idea has received more attention than the former, even if no reforms increasing gender equality have been conducted since 2013, while policy advancements have been made regarding social inclusion. Moreover, both ideas seem to have divided parties, with the leftist parties openly supporting social inclusion while conservative and confessional parties have been more reserved, especially when it comes to the rights of 'rainbow' families. Somewhat surprisingly, the idea of state-regulated gender equality through leave quotas seems to have received increasing support over time, even among the Finns Party and the Centre Party. However, it should be noted that the Centre Party has been more ambivalent than the Finns Party in this respect and that both parties, together with the Christian Democrats, have connected this issue to the preservation of the child home-care leave.

\subsection{Sweden}

In Sweden, the government and party discourses on parental leave during the 2010s also related to both social inclusion and gender equality. While the latter has been in a dominant position, the former has gained more attention over time (see Table 2).

At the beginning of the 2010s, the idea of social inclusion was discussed mainly by the conservative-liberal coalition in relation to improved leave rights for single moms and student families:
For those [parents] that are single, the possibility to use all parental leave days needs to be introduced. (The Alliance, 2010, p. 33)

In the same vein, the Liberals advocated stronger rights to leave for unemployed and sick parents, while the Centre Party supported self-employed parents' rights to leave. However, the conservative-liberal government also framed the idea of social inclusion in a negative way. In 2010, it envisaged stricter entitlement rules for immigrants for the sake of more effective integration:

The parental allowance will be adjusted to improve the chances of newly arrived foreign-born women to get a job. (Swedish Government, 2010)

In 2016, the Social-Democratic government launched a committee to prepare a restriction of eligibility rules for immigrant families with older children (Swedish Government, 2016a). In its preliminary report (SOU, 2016), the committee suggested a restriction in leave days for immigrant parents arriving with foreign-born children. The argument was that it would enhance the integration of immigrants and prevent unfairness in terms of 'over-compensating' benefits for immigrant parents' (SOU, 2016, pp. 10-12). In 2017, this restriction was enacted as a part of the 'migration' deal struck between the Social-Democratic coalition and the opposition. Accordingly, parents who immigrated when their child was between 12 and 24 months received 200 days

Table 2. Overview of government and party discourses regarding parental leave in Sweden during the 2010s.

\begin{tabular}{|c|c|c|c|}
\hline & 2010-2014 & 2014-2017 & 2018- \\
\hline \multicolumn{4}{|l|}{ Social inclusion } \\
\hline Government discourse & $\begin{array}{l}\text { GD (Reinfeldt) } 2010+/- \\
\text { GD (Reinfeldt) } 2012+\end{array}$ & $\begin{array}{l}\text { GD (Löfven) } 2014+ \\
\text { GD (Löfven) } 2015+ \\
\text { SOU 2016:73- } \\
\text { SOU 2017:101 + }\end{array}$ & \\
\hline Party discourse & $\begin{array}{l}\text { Left }(+) \\
\text { Lib/Con }+\end{array}$ & $\begin{array}{l}\text { SocDem/Left }+ \\
\text { Cen }+\end{array}$ & $\begin{array}{l}\text { SocDem + } \\
\text { Lib }+\end{array}$ \\
\hline \multicolumn{4}{|l|}{ Gender equality } \\
\hline Government discourse & SOU 2011:51 + & $\begin{array}{l}\text { GD (Löfven) 2014: +, } 0 \\
\text { GD (Löfven) } 2015+ \\
\text { SOU 2014:6 + } \\
\text { SOU 2015:50 +/- }\end{array}$ & $\begin{array}{l}\text { GD (Löfven) } 2019+ \\
\text { SOU } 2017+\end{array}$ \\
\hline Party discourse & $\begin{array}{l}\text { SocDem/Left/Lib/Cen }+ \\
\text { Con }+/(-) \\
\text { ChD/SwD- }\end{array}$ & $\begin{array}{l}\text { SocDem/Left/Lib/Cen }+ \\
\text { Con }+ \\
\text { ChD/SwD- }\end{array}$ & $\begin{array}{l}\text { SocDem (+) } \\
\text { Left/Lib }+ \\
\text { Con } 0 \\
\text { ChD/SwD- }\end{array}$ \\
\hline
\end{tabular}

Notes: 'Government discourse' relates to government declarations (GD) or committee reports (SOU). 'Party discourse' relates to party election manifestos or similar programmes. ' + ' denotes a positive position and ' - ' a negative position on social inclusion/gender equality, ' 0 ' denotes other mentions regarding parental leave. 'SocDem' is an abbreviation for Social Democrats. 'Left' for Left Party, 'Lib' for Liberal Party, 'Cen' for Centre Party, 'Con' for Conservatives, 'ChD' for Christian Democrats and 'SwD' for Sweden Democrats. Parentheses indicate an indirect position. The data can be retrieved from the Supplementary File. 
of parental allowance in total, and parents who immigrated when the child was over 24 months received 100 days in total (Swedish Government, 2017).

In the middle of the 2010s, the idea of social inclusion turned more towards same-sex and transgender families, so-called 'star' or 'rainbow' families. The 2014 and 2015 government declarations, as well as the 2017 committee report, suggested improved leave rights for these family constellations:

The parental leave insurance will be overhauled in order to make it easier for families that identify themselves as star families. (Swedish Government, 2014, p. 9)

The Social Democrats and the Left Party supported this idea in their election programmes, but did not connect it explicitly to the question of equal rights to parental leave. For instance, in their 2018 election programme, the Social Democrats called for higher competence among social care personnel and modernised legislation as a way to ease the lives of "star families" (Social Democrats, 2018, p. 26). The Left Party, which acknowledged 'star families' already in its 2010 election programme, took this discourse a step further by including all families in this category:

We want to see a feminist family policy based on reality, that we are a country of star families where families look different and are formed differently. (The Left Party, 2014)

As to gender equality, both the Swedish government and party discourses in the 2010s related mainly to how to make an already gender-equal parental leave system even more equal. In the conservative-liberal government's discourse, this was something that could be achieved through the existing reserved months, more flexibility, and the so-called gender-equality bonus (The Alliance, 2010). However, when the Social Democrats came back to power in 2014, the government's discourse changed. The gender equality bonus and the child home-care allowance was now portrayed as inefficient tools for changing the uneven division of parental leave, which led to their termination a couple of years later (Swedish Government, 2015a, 2016b). Instead, the government accentuated an expansion of the state-regulated parental quotas as a more efficient way to change parental behaviour in a more genderequal direction (SOU, 2014, 2015).

In 2015, the Löfven Government stated that it, as the "first feminist" government, was about to bring the Swedish parental leave policy back to the path of gender equality:

The world's first feminist government is now conducting policies that increase gender equality between men and women....A third month is to be reserved for each parent. (Swedish Government, 2015b, p. 16)

Furthermore, in the 2017 committee report on genderequal parenthood (SOU, 2017), the idea of gender equality was combined with higher flexibility in an ambition to introduce a "family week," which would be an extension of the current temporary leave for parents in order to increase parents' time together with their children (SOU, 2017; Swedish Government, 2020).

Even though the 2016 introduction of a third reserved month was approved without much discussion, the question of state-regulated leave quotas remained contested by some parties. While the Social Democrats, the Left Party and the Liberals explicitly supported quotas and criticised the child home-care allowance, the Christian Democrats and the nationalist-populist Sweden Democrats vehemently opposed state-regulated quotas and instead advocated more flexibility and freedom for parents to choose how children should be cared for, including the right to use child home-care allowance:

All families are unique and therefore parents themselves know best how they want to arrange the care of their children.... Remove the compulsory quotas and make the parental insurance more flexible-The days are to be freely transferable between parents or other close persons. (Christian Democrats, 2018b)

Meanwhile, the Centre Party and the Conservatives took something of a middle position by supporting higher flexibility and freedom of choice in matters of childcare, but refraining from explicitly criticising state-regulated leave quotas.

To sum up, while both the policy development and political discourses in Sweden during the 2010s have shifted back to a more traditional Social-Democratic path based on state-regulated gender equality, there has also been a development in the discourse on social inclusion. This discourse has increasingly highlighted parental leave rights for 'new' family formations and 'star' families, but has also demanded restrictions of unintended benefits for foreign-born children.

\section{Discussion and Conclusions}

The aim of this article was to investigate government and party discourses on parental leave in Finland and Sweden during the 2010s against the backdrop of ideas on social inclusion and gender equality. Based on our findings, we can draw the following conclusions.

First, while the focus of Finnish and Swedish government and party discourses during the 2010s has been more on gender equality than social inclusion, the latter idea received a more visible role over time, leading up to major reforms in Finland regarding the rights of single parents and 'rainbow' families. Also, in Sweden, this aspect of social inclusion became more visible over 
time. As can be expected, the idea of gender equality has played a more visible role in the Swedish discourse than in the Finnish. Sweden has also made its already gender-equal parental leave more equal through the introduction of the third reserved month in 2016, while Finland has not (thus far) succeeded to conduct further reforms in this field since the 2013 reform. While the increasing role of social inclusion, notably the rights of 'rainbow' and 'star families,' reflects contemporary changes in the family institution and international agreements (cf. Wong et al., 2019), it also relates to the increasing importance of policy transfer and social learning (Hulme, 2005). Not only have ideas and policy imperatives from the EU and the OECD influenced Finnish and Swedish discourses, it is also clear that Sweden has served as a role model for politicians and civil servants in Finland, especially when it comes to the implementation of gender equality in parental leave policy.

Second, in both countries, the ideas on social inclusion and gender equality in parental leave policy have been understood and implemented differently depending on the ideological stance of governments and parties. Leftist governments and leftist parties in both countries have generally and more explicitly advocated higher social inclusion for a greater diversity of family constellations. They have also advocated higher gender equality in parental leave through state-regulated quotas, while governments and parties on the right have instead advocated higher flexibility and freedom of choice for parent (cf. Hiilamo \& Kangas, 2009). However, in Finland, parties, except for the Christian Democrats, seem to have become more positively disposed towards the idea of gender-equal leave through longer and reserved months, which suggests that this particular version of the idea of gender equality is gaining acceptance across ideological lines.

Third, it seems that the Finnish and Swedish discourses on parental leave have become more similar during the 2010s, especially when it comes to the role that gender equality through individual parental quotas plays in the overall debate. Even if Sweden has been more successful in shaping its parental leave system in this direction, Finland has also locked in on this track. Also, the fact that Finland tried to reform its system in 2017-2018 and that the current government plans to introduce parental quotas that are even longer than those in Sweden (STM, 2021) shows that Finland is determined to close in on Sweden in this respect. The observed change in the Finnish party discourse towards a more positive disposition regarding gender equality may be of importance for the completion of a successful parental leave reform. However, although Finnish parties have become more positive towards leave quotas, they still differ in how to implement them, and notably what the role of the controversial child home-care leave should be. It is also noteworthy that even if Finnish discourse on gender-equal parental leave has become more similar to the Swedish, it still seems to be somewhat more 'traditional' than the
Swedish, with fewer mentions of gender equality or 'feminist' policy.

Since this article used only documentary data, we cannot say much about how ideas on social inclusion or gender equality have penetrated the deeper layers of governments or parties. For this, we need future research that employs also other data. Furthermore, the focus on governments and political parties is another limitation that could be rectified by studying also social partners and other major players. Nevertheless, this study shows that ideas play an important role for political discourse, and that such discourses are important drivers or blockers of reform. It seems not farfetched then that the observed convergence in parental leave discourse in Finland and Sweden may bring along higher convergence also in parental leave policy over time.

\section{Acknowledgments}

We are grateful for the constructive comments received from the reviewers and the editors during different stages of the process.

\section{Conflict of Interests}

The authors declare no conflict of interests.

\section{Supplementary Material}

Supplementary material for this article is available online in the format provided by the author (unedited).

\section{References}

Auth, D., \& Martinek, H. (2017). Social investment or gender equality? Aims, instruments, and outcomes of parental leave regulations in Germany and Sweden. In D. Auth., J. Hergenhan, \& B. Holland-Cunz (Eds.), Gender and family in European economic policy (pp. 153-176). Cham: Palgrave Macmillian.

Boréus, K., \& Bergström, G. (2017). Analyzing text and discourse: Eight approaches for the social sciences. London: Sage.

Cedstrand, S. (2011). Från idé till politisk verklighet: Föräldrapolitiken i Sverige och Danmark [From idea to political reality: Parental policy in Sweden and Denmark]. Umeå: Boréa.

Christian Democrats. (2018a). Lapsiystävällinen Suomi [A child-friendly Finland]. Helsinki: Christian Democrats. Retrieved from https://www.kd.fi/files/ 2018/06/KD_Perhepoliittinen-ohjelma_2018.pdf

Christian Democrats. (2018b). Du ska kunna lita på Sverige-Valmanifest [You need to be able to trust Sweden-Election manifesto]. The Christian Democrats. Retrieved from https:// se/du-ska-kunna-lita-pa-sverige

Dobrotić, I., \& Blum, S. (2020). Inclusiveness of parentalleave benefits in twenty-one European countries: 
Measuring social and gender inequalities in leave eligibility. Social Politics, 27(3), 588-614.

Duvander, A.-Z., \& Ellingsæter, A. (2016). Cash for childcare schemes in the Nordic welfare states: Diverse paths, diverse outcomes. European Societies, 18(1), 70-90.

Duvander, A.-Z., \& Johansson, M. (2012). What are the effects of reforms promoting fathers' parental leave use? Journal of European Social Policy, 22(3), 319-330.

Elomäki, A., Mustosmäki, A., \& Koskinen Sandberg, P. (2020). The sidelining of gender equality in a corporatist and knowledge-oriented regime: The case of failed family leave reform in Finland. Critical Social Policy. Advance online publication. https://doi.org/ 10.1177/0261018320947060

European Commission. (2019). Leave policies and practice for non-traditional families. Luxembourg: Publications Office of the European Union.

Evertsson, M., Jaspers, E., \& Moberg, Y. (2020). Parentalization of same-sex couples: Family formation and leave rights in five Northern European countries. In R. Nieuwenhuis \& W. van Lancker (Eds.), The Palgrave handbook of family policy (pp. 397-428). Cham: Palgrave Macmillan.

Eydal, G., Gíslason, I., Rostgaard, T., Brandth, B., Duvander, A.-Z., \& Lammi-Taskula, J. (2015). Trends in parental leave in the Nordic countries: Has the forward march of gender equality halted? Community, Work \& Family, 18(2), 167-181.

Eydal, G., Rostgaard, T., \& Hiilamo, H. (2018). Family policies in the Nordic countries: Aiming at equality. In G. Eydal \& T. Rostgaard (Eds.), Handbook in family policy (pp. 195-208). Cheltenham: Edward Elgar.

Ferrarini, T., \& Duvander, A.-Z. (2010). Earner-carer model at the crossroads: Reforms and outcomes of Sweden's family policy in a comparative perspective. International Journal of Health Services, 40(3), 373-398.

Finnish Government. (2011). Programme of PM Jyrki Katainen's Government: An open, fair and confident Finland. Helsinki: Finnish Government.

Finnish Government. (2019). Programme of PM Sanna Marin's Government: Inclusive and competent Finland-A socially, economically and ecologically sustainable society. Helsinki: Finnish Government.

Försäkringskassan. (2020a). Föräldrapenning [Parental allowance]. Försäkringskassan. Retrieved from https://www.forsakringskassan.se/privatpers/ foralder/nar_barnet_ar_fott/foraldrapenning

Försäkringskassan. (2020b). Förändringar inom socialförsäkrings- och bidragsområdena 196801-01-2019-09-01. [Changes in social insurance and allowance area 1968-01-01-2019-09-01]. Stockholm: Försäkringskassan. Retrieved from https://www. forsakringskassan.se/wps/wcm/connect/3ee6f240c47a-4ba9-8b29-8a8b53acc887/forandringar-inomsocialforsakringen.pdf?MOD=AJPERES\&CVID=
Freeden, M. (1996). Ideologies and political theory. A conceptual approach. Oxford: Clarendon.

Gustafsson, S., \& Stafford, F. (1992). Child care subsidies and labor supply in Sweden. The Journal of Human Resources, 27(1), 204-230.

Haataja, A., \& Nyberg, A. (2006). Diverging paths? The dual-earner/dual-carer model in Finland and Sweden in the 1990s. In A. Ellingsaeter \& A. Leira (Eds.), Politicising parenthood in Scandinavia (pp. 217-239). Bristol: Policy Press.

Häusermann, S., Picot, G., \& Geering, D. (2013). Review article: Rethinking party politics and the welfare state-Recent advances in the literature. British Journal of Political Science, 43(1), 221-240.

Hiilamo, H. (2002). The rise and fall of Nordic family policy? Historical development and changes during the 1990s in Sweden and Finland. Helsinki: Stakes.

Hiilamo, H., \& Kangas, O. (2009). Trap for women or freedom to choose? The struggle over cash for child care schemes in Finland and Sweden. Journal of Social Policy, 38(3), 457-475.

Hsieh, H.-F., \& Shannon, S. (2005). Three approaches to qualitative content analysis. Qualitative Health Research, 15(9), 1277-1288.

Hulme, R. (2005). Policy transfer and the internationalisation of social policy. Social Policy \& Society, 4(4), 417-425.

Kela. (2020). Families. Kela. Retrieved from https://www. kela.fi/web/en/families

Kuebler, D. (2007). Understanding the recent expansion of Swiss family policy: An idea-centred approach. Journal of Social Policy, 36(2), 217-237.

Lammi-Taskula, J., \& Takala, P. (2009). Finland: Negotiating tripartite compromises. In S. Kamerman \& P. Moss (Eds.), The politics of parental leave policies (pp. 87-102). Bristol: Policy Press.

Lewin, L. (2020). Konsten att bilda regering när ingen har majoritet [The art of forming a government when no one has majority]. Göteborg: Daidalos.

Lundqvist, Å. (2007). Familjen i den svenska modellen [The family in the Swedish model]. Umeå: Boréa.

Morel, N., Palier, B., \& Palme, J. (2012). Beyond the welfare state as we knew it. In N. Morel, B. Palier, \& J. Palme (Eds.), Towards a social investment state (pp. 1-30). Bristol: Policy Press.

Moring, A., \& Lammi-Taskula, J. (2021). Parental leave reforms in Finland 1977-2019 from a diversity perspective. Social Inclusion, 9(2), 338-349.

NOSOSCO. (2017). Social protection in the Nordic countries 2016/2016. Copenhagen: Nordic Social Statistical Committee.

Nyberg, A. (2000). From foster mothers to child care centers: A history of working mothers and child care in Sweden. Feminist Economics, 6(1), 5-20.

Nyby, J. (2020). Politicizing family policy reform. The case of Finland. Åbo: Åbo Akademi University Press.

Nygård, M., Nyby, J., \& Kuisma, M. (2019). Discarding social investment and redistribution in the name of 
austerity? The case of Finnish family policy reforms 2007-2015. Policy and Society, 38(3), 519-536.

Salmi, M., \& Lammi-Taskula, J. (2014). Policy goals and obstacles for fathers' parental leave in Finland. In G. Eydal, \& T. Rostgaard (Eds.), Fatherhood in the Nordic Welfare states: Comparing care policies and practice (pp. 303-324). Bristol: Policy Press.

Social Democrats. (2018). Det största trygghetsprogrammet $i$ modern tid. Socialdemokraternas valmanifest 2018 [The largest security program in modern times. Social Democrats' election manifesto 2018]. Stockholm: Swedish Social Democratic Party. Retrieved from https://www.socialdemokraterna.se/ download/18.12ce554f16be946d04641321/ 1568881590668/valmanifest-2018.pdf

SOU. (2014). Män och jämställdhet [Men and gender equality]. Stockholm: Fritzes.

SOU. (2015). Hela lönen, hela tiden-Utmaningar för ett jämställt arbetsliv [The whole pay, all the timeChallenges for a gender-equal working life]. Stockholm: Fritzes.

SOU. (2016). Begränsningar i föräldrapenningen för föräldrar som kommer till Sverige med barn [Limitations of parental allowance for parents that arrive in Sweden with children] (Statens offentliga utredningar 2016:73). Stockholm: Fritzes.

SOU. (2017). Jämställt föräldraskap och goda uppväxtvilIkor för barn-En ny modell för föräldraförsäkringen [Gender-equal parenthood and beneficial conditions for children to grow up in]. Stockholm: Fritzes.

Stanfors, M. (2007). Education, labor force participation and changing fertility patterns. A study of women and socioeconomic change in twentieth century Sweden. Lund: Lund University.

Statistics Finland. (2017). Finland/Sweden comparison: No great differences in working among mothers of small children. Statistics Finland. Retrieved from https://www.stat.fi/tietotrendit/artikkelit/2017/ finlandsweden-comparison-no-great-differencesin-working-among-mothers-of-small-children

STM. (2011). Vanhempainvapaatyöryhmän muistio [PM of the family leave committee]. Helsinki: Ministry of Social Affairs and Health.

STM. (2015). Monimuotoiset perheet [Diverse families]. Helsinki: Ministry of Social Affairs and Health.

STM. (2021). Hallituksen esityksen luonnos perhevapaauudistuksesta valmistunut [The government's proposal for family leave reform]. Sosiaali- ja terveysministeriö. Retrieved from https://stm.fi/-/hallituksen-esityksen-luonnosperhevapaauudistuksesta-valmistunut

Swedish Government. (2010). Government declaration (18 September 2010). Stockholm: Swedish Government.

Swedish Government. (2014). Government declaration (3 October 2014). Stockholm: Swedish Government.
Swedish Government. (2015a). Det kommunala vårdnadsbidraget avskaffas [Abolition of the muncipal child home-care leave] (Government Bill 2014/15: 147). Stockholm: Swedish Government.

Swedish Government. (2015b). Government declaration (15 September 2015). Stockholm: Swedish Government.

Swedish Government. (2016a). Jämställt föräldraskap och goda uppväxtvillkor för barn [Gender-equal parenthood and beneficial conditions for children to grow up in] (Kommittédirektiv 2016:10). Stockholm: Swedish Government.

Swedish Government. (2016b). Proposition 2016/2017:1, utg.omr. 12 [Budget proposition for 2017]. Stockholm: Swedish Government.

Swedish Government. (2017). Begränsningar i föräldrapenningen för föräldrar som kommer till Sverige med barn [Limitations of parental allowance for parens that arrive in Sweden with children] (Government bill 2016/17:154). Stockholm: Swedish Government.

Swedish Government. (2020). Proposition 2020/2021:1, utg.omr.12 [Budget proposition for 2021]. Stockholm: Swedish Government.

The Alliance. (2010). Jobbmanifestet. Valmanifest 2010-2014 [The Job Manifesto. Election manifesto 2010-2014]. Stockholm: Moderata Samlingspartiet, Centerpartiet, Folkpartiet liberalerna.

The Left Party. (2014). Vänsterpartiets valplattform för riksdagsvalet 2014 [The Left Party's election manifesto 2014]. The Left Party. Retrieved from https://www.vansterpartiet.se/vansterpartietsvalplattform-for-riksdagsvalet-2014

Weckström, S. (2014). Defamilialisation policies and attitudes and behaviour among mothers in twelve European countries. Do results for Denmark, Finland and Sweden differ from the others? Finnish Yearbook of Population Research, 49(1), 5-29.

Wennemo, I. (1994). Sharing the costs of children. Studies in the development of family support in the OECD Countries. Stockholm: University of Stockholm.

Wong, E., Jou, J., Raub, A., \& Heymann, J. (2019). Comparing the availability of paid parental leave for same-sex and different-sex couples in 34 OECD countries. Journal of Social Policy, 49(3), 525-545.

Ylikännö, M., Hakovirta, M., \& Salin, M. (2016). Miten perhevapaat tulisi jakaa äidin ja isän kesken? Asenteet Suomessa ja muualla Euroopassa [How to share family leaves between the mother and the father? Opinions in Finland and elsewhere in Europe]. In A. Haataja, I. Airio, M. Saarikallio-Torp, \& M. Valaste (Eds.), Laulu 573566 perheestä. Lapsiperheet ja perhepolitiikka 2000-luvulla [A song about 573,566 families. Families with children and family policy in the 2000s] (pp. 226-247). Helsinki: Kela. 


\section{About the Authors}

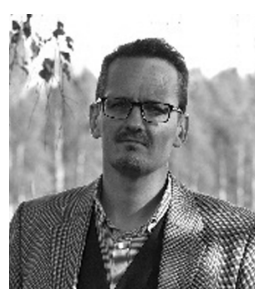

Mikael Nygård is Professor of Social Policy at Åbo Akademi University, Finland. His research interests include welfare state reforms and comparative welfare state analysis with a special focus on family policy within the Nordic countries. His research also covers various aspects of social inclusion and participation in relation to different population groups.

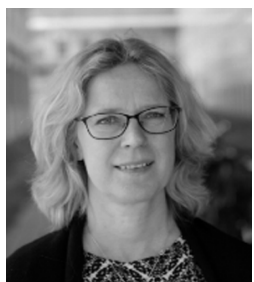

Ann-Zofie Duvander is Professor of Sociology at Mid University and Professor of Demography at Stockholm University. Her research interests include family policy and her research often focus on parental leave use and consequences. She has also studied the family and work-connection and income trajectories in couples following childbirth. Recently she has been involved in research on older couples' relationships. Duvander is one of two coordinators of the International Network for Leave Policies and Research (leavenetwork.org). 